\title{
Seasonal Occurrence of Cetaceans along the Washington Coast from Passive Acoustic Monitoring
}

\author{
CANDICE K. EMMONS, M. BRADLEY HANSON, and MARC O. LAMMERS
}

\section{Introduction}

Estimates of cetacean abundance, density, and distribution are necessary to understand the role of cetaceans in marine ecosystems and to identify potential anthropogenic threats to managed and endangered cetaceans. Along the U.S. west coast, cetaceans are at risk of fishery interactions, entanglement, ship strike (Douglas et al., 2008; Carretta et al., 2014a), and anthropogenic sound sources such as seismic surveys, military sonar, and other vessel noise (Emmons et al., 2019).

Many cetacean species inhabit the outer coast of Washington State. These species are managed under the U.S. Marine Mammal Protection Act and

Candice K. Emmons is with the Conservation Biology Division, Northwest Fisheries Science Center, National Marine Fisheries Service, NOAA, 2725 Montlake Boulevard East, Seattle, WA 98112 (email: candice.emmons@noaa. gov). M. Bradley Hanson is with the Conservation Biology Division, Northwest Fisheries Science Center, National Marine Fisheries Service, NOAA, 2725 Montlake Boulevard East, Seattle, WA 98112. Marc O. Lammers is with the Hawaiian Islands Humpback Whale National Marine Sanctuary, 726 South Kihei Road, Kihei, HI 96753.

doi: https://doi.org/10.7755/MFR.82.3-4.2

ABSTRACT-Seasonal occurrence of cetaceans along the Pacific Coast of Washington has been difficult to characterize because decreased daylight and inclement weather conditions result in a lack of consistent survey effort. Therefore, passive acoustic recorders were deployed at four sites along the Washington coast from 2008 to 2013 to record and detect sound-producing cetaceans. The most frequently detected cetaceans were gray whales, Eschrictius robustus; humpback whales, Megaptera novaengliae; sperm whales, Physeter include several stocks listed under the U.S. Endangered Species Act (Carretta et al., 2014b). The abundance and population density of cetaceans in the California Current off the U.S. Pacific Coast, including the Washington coast, has been estimated from summer and fall ship and aerial surveys (Barlow and Forney, 2007; Barlow, 2010; Chandler and Calamboki$\left.\operatorname{dis}^{1}\right)$. However, species distribution in this area likely changes between seasons, since many cetacean species undertake long-distance annual migrations (Calambokidis et al., 2001). Forney and Barlow (1998) found that half of the abundance estimates for species surveyed off the California coast exhibited significant differences between the winter and summer surveys indicating that species' distribution in the California current changes seasonally. Determining cetacean seasonal distribution patterns is difficult and cost

${ }^{1}$ Chandler, T., and J. Calambokidis. 2003. 2002 aerial surveys for harbor porpoise and other marine mammals off Oregon, Washington and British Columbia. Unpubl. rep. on file at Marine Mammal Laboratory, Alaska Fish. Sci. Cent., NMFS, NOAA, 7600 Sand Point Way NE, Seattle, WA 98115.

macrocephalus; and killer whales, Orcinus orca. Unlike the results from previous surveys, year-round acoustic monitoring indicates that migratory species such as gray, humpback, and sperm whales use parts of the Washington coast throughout the year. This information is essential for estimating the potential for human interactions such as entanglement or ship strikes with these species.

Seasonal occurrence of the four species was variable between the four sites, even among those sites that were closest in prohibitive due to protracted periods of inclement weather, remote access, and short daylight hours.

Previous attempts to better describe the year-round occurrence of cetaceans along the Washington coast have been limited temporally and spatially. Aerial surveys were conducted in the late 1980's and again in the 1990's (Shelden et al., 2000; Green et $\mathrm{al}^{2}{ }^{2}$ ). More recently non-systematic ship surveys have been conducted to locate endangered southern resident killer whales, Orcinus orca, in winter and spring months along the Washington and Oregon coasts (Hanson et al., 2010). Acoustic monitoring and associated small boat surveys have been employed to monitor marine mammal occurrence in the U.S. Navy Northwest Training Range Complex (Oleson and Hildebrand, 2012; Trickey et al., 2015), but these have been limited in space to two sites on the central

${ }^{2}$ Green, G. A., J. J. Brueggeman, R. A. Grotefendt, C. E. Bowlby, M. L. Bonnell, and K. C. Balcomb. 1992. Cetacean distribution and abundance off Oregon and Washington 1989-1990. In J. J. Brueggerman (Editor), OR and WA marine mammal and seabird surveys. Ebasco Environ. Rep., Bellevue, WA (unpubl.), p. 1-100.

proximity. These results indicate that caution should be used when extrapolating the results from a single site to a larger scale. Combining multiple sites into a loose network of recorders allowed us to characterize the spatial and seasonal occurrence of these cetaceans on the Washington coast during times of the year when aerial and ship surveys are not feasible. Additionally, we provide a baseline for monitoring yearly shifts in occurrence due to changing population demographics, oceanographic conditions, or anthropogenic inputs. 
Table 1.-Recording effort for each location.

\begin{tabular}{|c|c|c|c|c|c|}
\hline Location & Dates of recording & $\begin{array}{l}\text { Depth } \\
\text { (meters) }\end{array}$ & $\begin{array}{l}\text { Sampling } \\
\text { rate }(\mathrm{kHz})\end{array}$ & $\begin{array}{c}\text { Seconds } \\
\text { on/off }\end{array}$ & $\begin{array}{l}\text { Total recording } \\
\text { time (days) }\end{array}$ \\
\hline Cape Flattery offshore & $\begin{array}{l}\text { Oct 2008-Mar } 2009 \\
\text { Sep 2010-Jul } 2011 \\
\text { Oct 2011-Aug } 2012 \\
\text { Sep 2012-Sep } 2013\end{array}$ & $\begin{array}{l}174 \\
169 \\
170 \\
168\end{array}$ & $\begin{array}{l}25 \\
25 \\
25 \\
25\end{array}$ & $\begin{array}{l}30 / 420 \\
30 / 600 \\
30 / 600 \\
30 / 600\end{array}$ & $\begin{array}{r}154 \\
334 \\
336 \\
371 \\
1,195\end{array}$ \\
\hline Cape Flattery inshore & $\begin{array}{l}\text { Oct 2008-Feb } 2009 \\
\text { Sep 2010-Apr } 2011 \\
\text { Oct 2011-Mar } 2012 \\
\text { Aug 2012-Nov } 2012\end{array}$ & $\begin{array}{l}115 \\
120 \\
115 \\
115\end{array}$ & $\begin{array}{l}25 \\
25 \\
25 \\
25\end{array}$ & $\begin{array}{l}30 / 420 \\
30 / 600 \\
30 / 600 \\
30 / 600\end{array}$ & $\begin{array}{r}145 \\
216 \\
187 \\
99 \\
647\end{array}$ \\
\hline Westport & $\begin{array}{l}\text { Oct 2008-Feb } 2009 \\
\text { Nov 2010-Aug } 2011 \\
\text { Oct 2011-Aug } 2012 \\
\text { Oct 2012-Jun } 2013\end{array}$ & $\begin{array}{l}63 \\
64 \\
64 \\
64\end{array}$ & $\begin{array}{l}25 \\
25 \\
25 \\
25\end{array}$ & $\begin{array}{l}30 / 420 \\
30 / 600 \\
30 / 600 \\
30 / 600\end{array}$ & $\begin{array}{r}145 \\
308 \\
328 \\
222 \\
1,003\end{array}$ \\
\hline Columbia River & $\begin{array}{l}\text { Mar 2008-Jul } 2008 \\
\text { Dec 2008-Apr } 2009 \\
\text { Oct 2010-Sep } 2011 \\
\text { Oct 2011-Nov } 2011\end{array}$ & $\begin{array}{r}80 \\
80 \\
111 \\
115\end{array}$ & $\begin{array}{l}25 \\
25 \\
25 \\
25\end{array}$ & $\begin{array}{l}30 / 300 \\
30 / 420 \\
30 / 600 \\
30 / 600\end{array}$ & $\begin{array}{r}71 \\
150 \\
336 \\
53 \\
610\end{array}$ \\
\hline
\end{tabular}

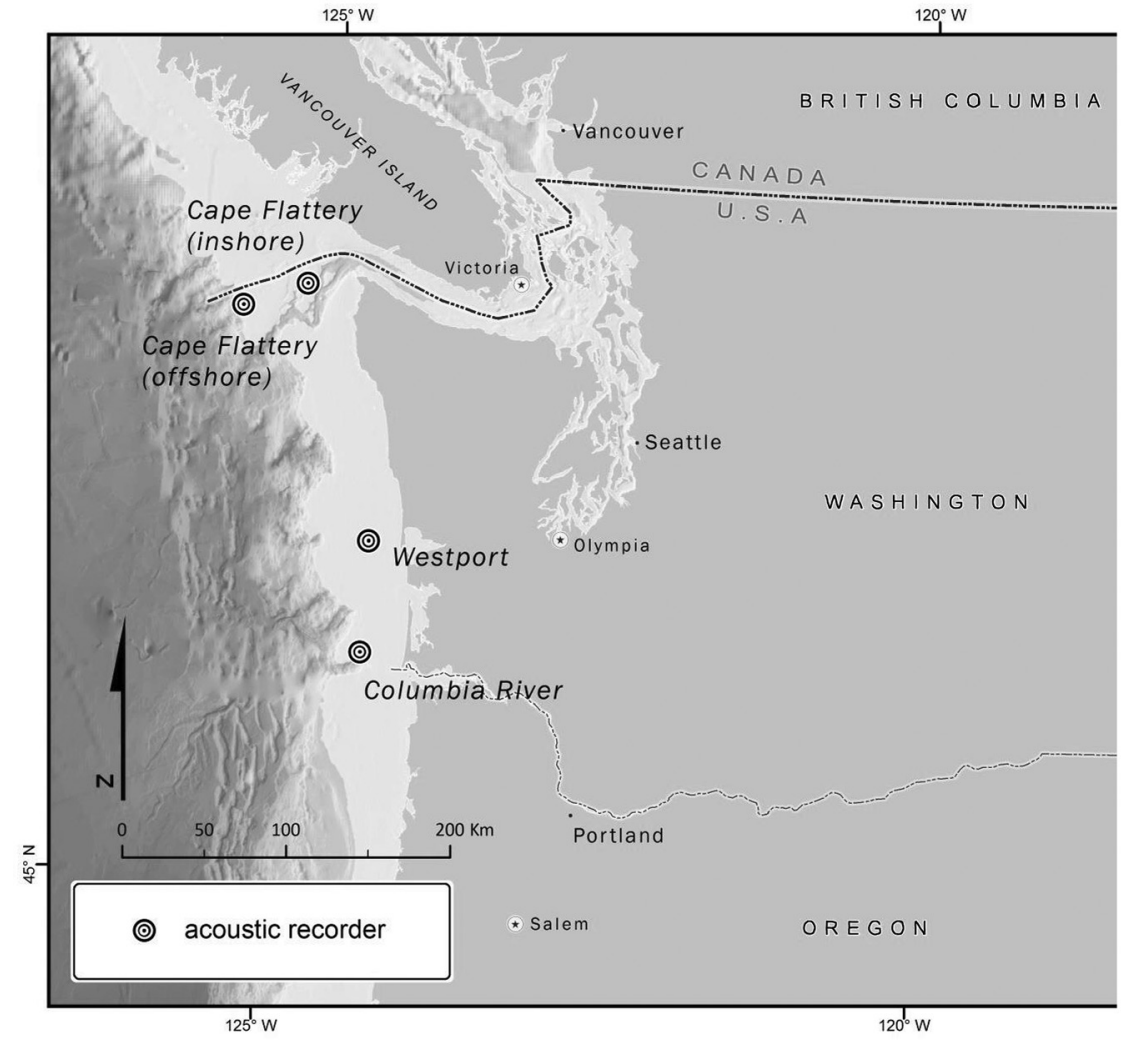

Figure 1.-Deployment locations of Ecological Acoustic Recorders (EAR's) on the Washington coast.

Washington coast. It is difficult to determine how representative these are of coastwide and year-round cetacean occurrence.
As a part of a larger monitoring effort to examine resident killer whale movements from central California to the northwest tip of Washington State
(Hanson et al., 2013), autonomous passive acoustic recorders were deployed at four sites along the Washington coast (Fig. 1). While the primary focus was to detect endangered southern resident killer whales during the winter and spring months, these recorders provided near year-round monitoring of sound-producing cetaceans. Here we describe the seasonal occurrence of the most frequently detected cetacean species along the Washington coast determined through passive acoustic monitoring: gray whales, Eschrictius robustus; humpback whales, Megaptera novaengliae; sperm whales, Physeter macrocephalus; and killer whales, Orcinus orca. This will provide the data necessary for determining how representative the previous studies that were limited spatially and seasonally are of coast-wide occurrence patterns.

\section{Methods}

\section{Study Area}

Ecological acoustic recorders (EAR's) (Lammers et al., 2008) were deployed at four sites spanning the continental shelf along the Washington coast from April 2008 to August 2013 (Fig. 1, 2; Table 1). Each recorder was part of a subsurface mooring that positioned the recorder approximately mid-water column (Table 1). Acoustic recorder locations were selected based on various factors which included previous killer whale sightings, sites where enhanced productivity would likely be concentrated due to bathymetric features, i.e., canyons heads (Denman and Powell, 1984; Mackas et al., 1997; Allen et al., 2001), accessibility for mooring deployment and recovery, and to reduce the likelihood of interactions with local fisheries (Hanson et al., 2013).

\section{Data Collection}

Each EAR is composed of four principal components: 1) the environmental interface module (hydrophone and water/pressure proof case), 2) the signal-conditioning module including the analog-to-digital device, 3) the central processing and storage unit, and 4) 


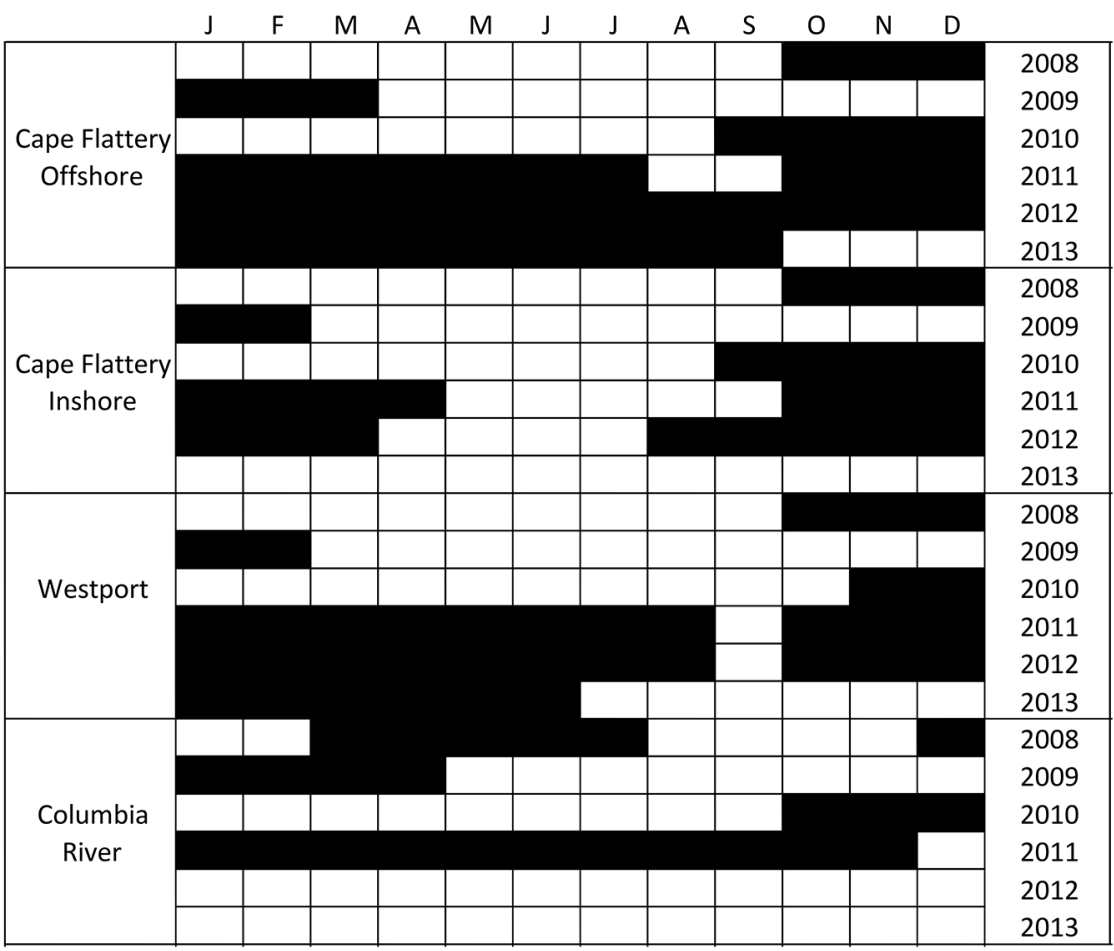

Figure 2.-Annual recorder effort by location.

the power supply. The system utilizes a hydrophone with a response sensitivity of $-193.5 \mathrm{~dB}$ that is flat from $1-28$ $\mathrm{kHz}(+/-1.5 \mathrm{~dB})$. Additional details on the specifications of the EAR are provided in Lammers et al. (2008).

In this study, EAR's were programmed to record on a 5-10\% duty cycle depending on the year of deployment: $10 \%$ in $2008,7 \%$ in 2009 , and $5 \%$ for all subsequent years (Table 1). This resulted in $30 \mathrm{sec}$ of continuous recording every 300 to $600 \mathrm{sec}$. Previous studies have shown that a reduced duty cycle may result in an underestimation of the time that species like killer whales, who vocalize in bouts, are acoustically present in the data set (Riera et al., 2013). Thomisch et al. (2015) found that a duty cycle which results in many short listening periods is preferred since it results in many daily samples, accounts for variability in vocal behavior, and is best suited for assessing acoustic presence.

To account for the differences in duty cycle between years, we used daily vocal occurrence as our unit of measure as in Hanson et al. (2013), in which the results indicated that the decreased duty cycle did not negatively affect the monthly detection rate of resident killer whales. The combination of a longer duty cycle and larger battery packs allowed for a yearlong service life, except in cases of delays in deployment schedules, mooring failures, instrument service life limitations, or fishing gear interactions (Table 1).

The sampling rate used on all deployments was $25 \mathrm{kHz}$ which provided $12.5 \mathrm{kHz}$ of bandwidth. This was chosen as a compromise between the need to preserve hard-drive space and battery life while also providing enough information from individual recordings to identify killer whales (Hanson et al., 2013). The restricted bandwidth, calls from allospecifics, and increased seasonal ambient noise below $500 \mathrm{~Hz}$ limited which species we were reliably able to detect and identify. Therefore, odontocete sounds above $12.5 \mathrm{kHz}$ and mysticete sounds below $500 \mathrm{~Hz}$ were not included in this analysis.

For each deployment, all 30-sec recordings were sorted by day (the number of files per day was determined by the duty cycle) and then concatenated and converted into .wav files using a custom script in MATLAB ${ }^{3}$. The resulting files were reviewed visually and aurally in Raven $\mathrm{Pro}^{4}$, and the sound sources present in the frequency range monitored were classified manually by comparing them to previously published descriptions of species-specific call and click types (Table 2). Those .wav files containing killer whale sounds were further reviewed, and discrete calls were compared to a catalog of pod and community specific dialects to determine the killer whale ecotype, community, and pod, if possible (Ford, 1987).

For each species monitored, we determined the daily vocal presence, which indicates that one or more individual was in the detection range of the recorder and produced a call. Occurrence was summarized on a 3-mo seasonal scale (fall: September-November, winter: December-February, spring: March-May, and summer: June-August) to account for gaps in monitoring due to equipment failure, fisheries interactions, and instrument deployment schedules while capturing migration patterns and changes in environmental conditions. Seasonal vocal presence for the study period was determined for each season by calculating the percentage of daily vocal presence normalized by the total number of days monitored in that season.

The observed and expected occurrence under a null model was summarized seasonally for each location using methods described in Hanson et al. (2013). To account for unequal sam-

${ }^{3}$ MathWorks. 2014. MATLAB release 2014b. The Mathworks, Inc. Natick, Mass. (http://www. mathworks.com/products/matlab/). Mention of trade names or commercial firms does not imply endorsement by the National Marine Fisheries Service, NOAA.

${ }^{4}$ Bioacoustics Research Program. 2011. Raven Pro: Interactive Sound Analysis Software (Version 1.4). The Cornell Lab of Ornithology, Ithaca, N.Y. (http://www.birds.cornell.edu/raven). 
Table 2.-Description of sounds used to identify species. Each spectrogram is $60 \mathrm{sec}$ long and displays the full bandwidth, $12.5 \mathrm{kHz}$, monitored.

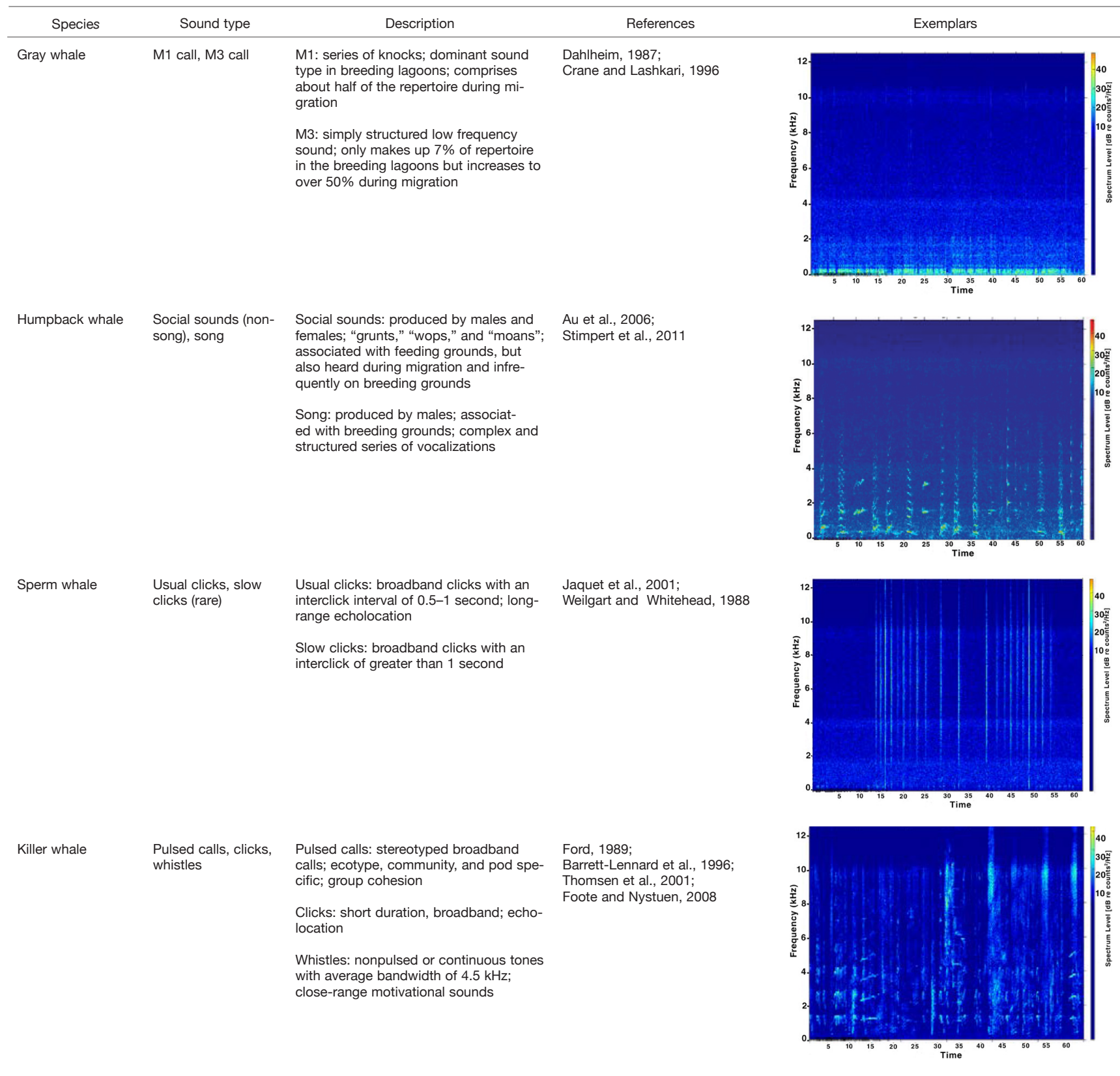

pling between seasons, the expected occurrence was estimated by multiplying the total number of days with detections in a given season by the proportional contribution of days monitored in that season (total number of days for a season divided by the total number of days monitored during that season in the study). For each species, differences in seasonal vocal presence and year-round occurrence at each location were determined using analysis of variance (ANOVA). Post hoc Tukey tests were also run to further investigate the differences between each pair of seasons and locations.

\section{Results}

Between 2008 and 2013, the number of days monitored at each site was variable (Fig. 2, Table 1). Since the primary interest in killer whale monitoring was to fill the data gap of winter and spring movements, de- 

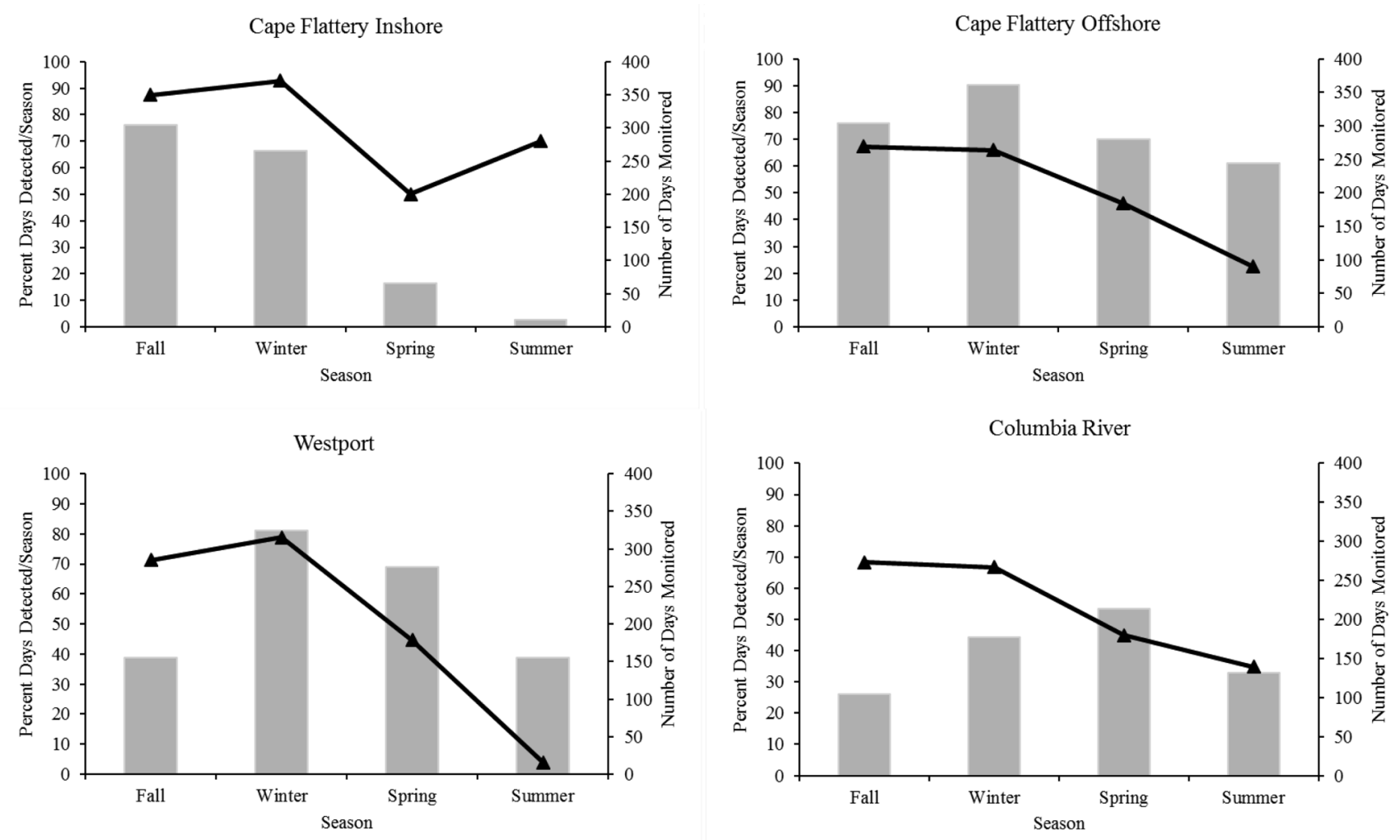

Figure 3.-Bars represent the seasonal recording effort. Diamonds represent the percentage of monitored days with gray whale detections at each location in a season.

ployments and recoveries of moorings were scheduled during the summer and fall months. This, combined with fishing gear interactions and instrument life limitations, restricted the summer monitoring effort. The combination of a longer recording duty cycle and larger battery packs allowed for a year-long service life, which led to increased effort beginning in 2011.

The most common cetacean species detected during the monitoring period are, in decreasing order of occurrence: gray whales, humpback whales, killer whales, and sperm whales $(60 \%, 46 \%$, $19 \%$, and $13 \%$ of all days monitored at all sites, respectively). Additionally, there were a number of sounds that have not been identified to species. These include unidentified delphinid clicks and whistles, pinniped calls, signals occurring below $500 \mathrm{~Hz}$, and some sounds that did not have an adequate signal to noise ratio to be identi- fied. Details of species-specific occurrence are described below.

\section{Gray Whales}

Detections of gray whales were most common at all four sites during the fall and winter seasons, declined during the spring season, and were the lowest during the summer (Fig. 3). This trend was the weakest at the Columbia River site. At both of the nearshore sites, Cape Flattery inshore and Westport, gray whales were detected on more days than expected during the fall and winter (Fig. 3). At all sites, occurrence during the spring matched the expected occurrence, while summer occurrence was higher than expected at the Cape Flattery offshore and Columbia River sites (Fig. 4). A one-way ANOVA showed a significant difference in the seasonal occurrence of gray whales at all sites combined $(F(3,44)=4.24, P=0.01)$, with higher occurrence in fall than in spring and summer (Tukey's test, $P<0.05$ ). There was no significant difference in the year-round occurrence among the sites $(F(3,6)=2.55, P=0.068)$.

\section{Humpback Whales}

Humpback whales were detected at each site in all seasons monitored with their occurrence peaking at all sites during fall months (September-November) and the lowest levels of occurrence during winter and spring months (Fig. 5). Occurrence in all seasons was lower than expected at the two southern sites, Westport and the Columbia River (Fig. 4). At the Cape Flattery inshore site, occurrence was higher than expected during the fall and winter (Fig. 3). The Cape Flattery offshore site had the highest occurrence of humpbacks whales throughout the year, and occurrence was higher than expected in all seasons (Fig. 4). A oneway ANOVA showed a significant difference in the seasonal occurrence of 


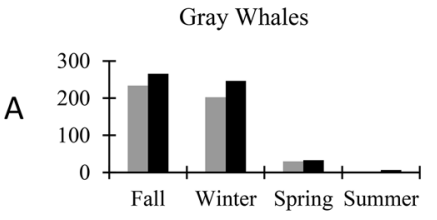

Gray Whales
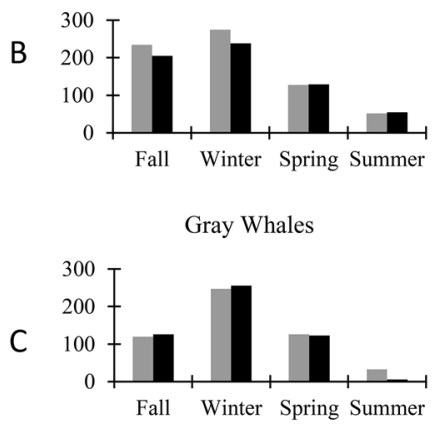

Gray Whales

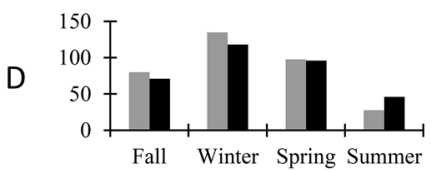

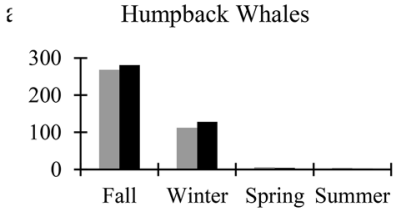

Humpback Whales

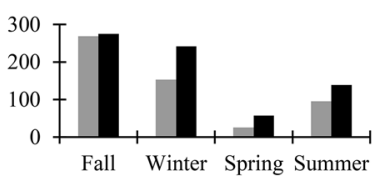

Humpback Whales

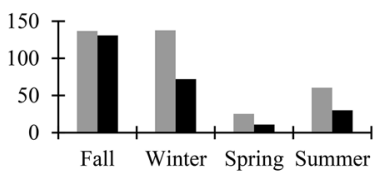

Humpback Whales

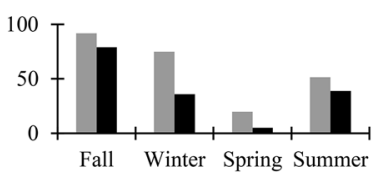

Sperm Whales

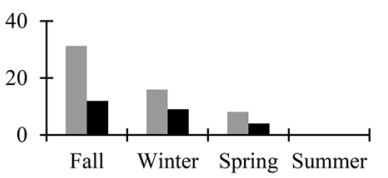

Sperm Whales

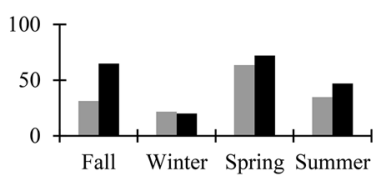

Sperm Whales

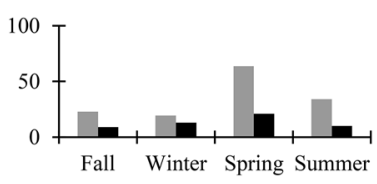

Sperm Whales

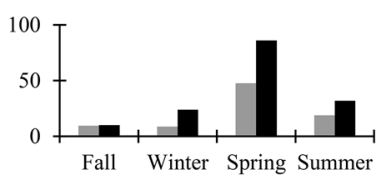

Killer Whales

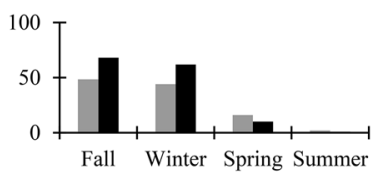

Killer Whales

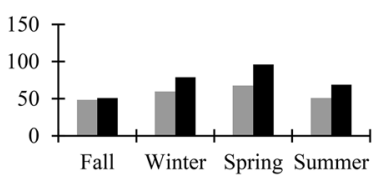

Killer Whales

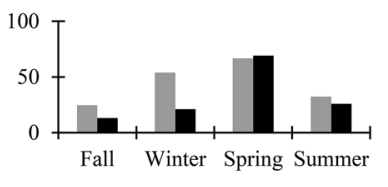

Killer Whales

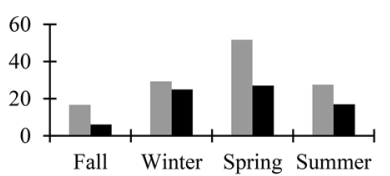

Figure 4.- Seasonal observed occurrence (black bars) versus expected occurrence (gray bars) for each species at (a) Cape Flattery Inshore, (b) Cape Flattery Offshore, (c) Westport, and (d) Columbia River.

humpback whales at all sites combined $(F(3,43)=2.82, \quad P=0.00)$, with higher occurrence in fall than in other seasons (Tukey's test, $P<0.05$ ). There was no significant difference in the year-round occurrence among the sites $(F(3,43)=2.39, P=0.08)$. Singing behavior was detected at all sites during the fall and extended into December and January in some cases, while social sounds were detected throughout the year at all sites.

\section{Sperm Whales}

Sperm whales were detected at all sites in every season, but their occurrence varied between sites and seasons (Fig. 6). The two near-shore sites had low levels of occurrence $(<5 \%$ of days monitored) in each season with minor peaks in the spring. The occurrence at these two sites was less than expected in all seasons (Fig. 4). Sperm whales were more frequently detected at the Cape Flattery Offshore and
Columbia River sites. Occurrence at these sites was higher than expected in all seasons except during the winter at Cape Flattery offshore (Fig. 4). The spring peak in detections was greatest at the Columbia River site with sperm whales detected on $43.5 \%$ of days as opposed to $26.1 \%$ at the Cape Flattery offshore site. A one-way ANOVA indicated there was no significant difference in seasonal occurrence of sperm whales at all sites combined $(F(3,43)=0.849, P=0.5)$. There was a significant difference in the year-round occurrence of sperm whales among the sites $(F(3,43)=8.25, P=0.00)$, with significant differences between the near-shore sites and the Cape Flattery offshore and Columbia River sites (Tukey's test, $P<0.05$ ).

\section{Killer Whales}

Killer whales were detected at each site in every month monitored (Fig. 7). In every season, killer whale de- tections were more frequent at the two northern sites, Cape Flattery inshore and offshore, and occurrence was greater than expected in all seasons at the offshore site and during the fall and winter at the inshore site (Fig. 4). At the two southern sites, Westport and the Columbia River, occurrence was less than expected in all seasons except for spring at the Westport site (Fig. 4). At both southern sites, fisheating "resident" killer whales were most frequently detected between the months of January and June. All these resident detections were of the southern resident community except for one in March 2012. At the northern sites both northern and southern resident killer whales were detected frequently.

During the period that southern resident occurrence is highest at the southern sites (January-April) northern residents were detected at the northern sites more frequently. Additionally, there was an increase in north- 
Cape Flattery Inshore

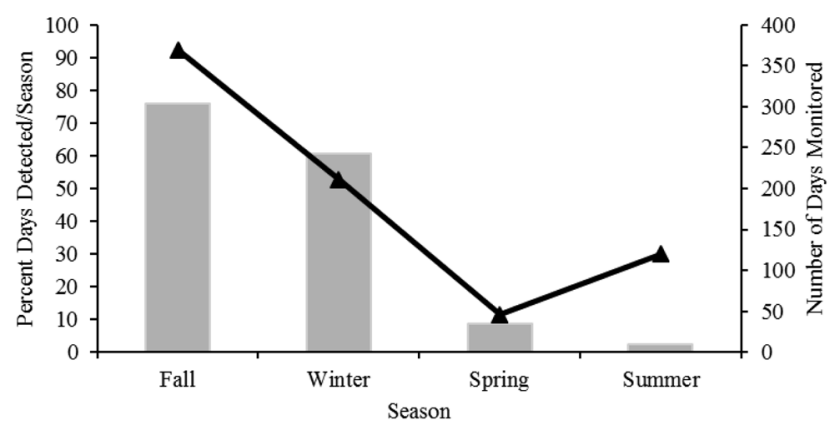

Westport

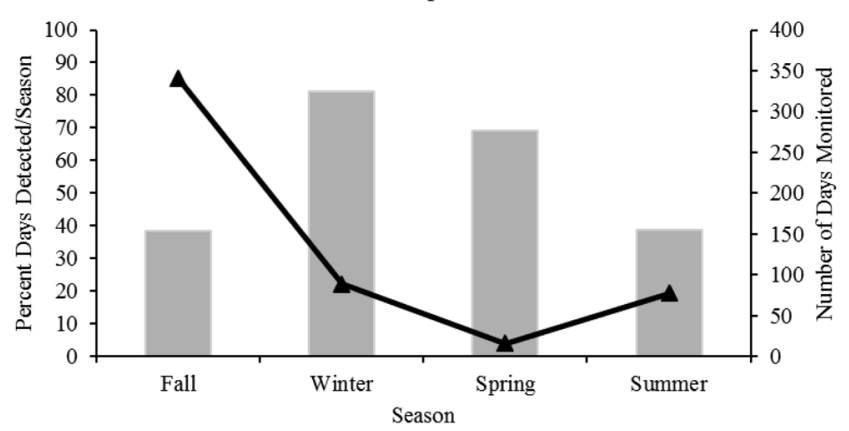

Cape Flattery Offshore

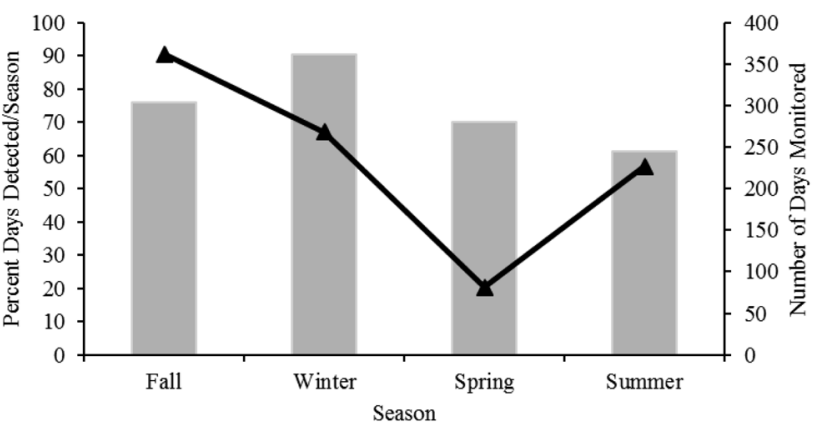

Columbia River

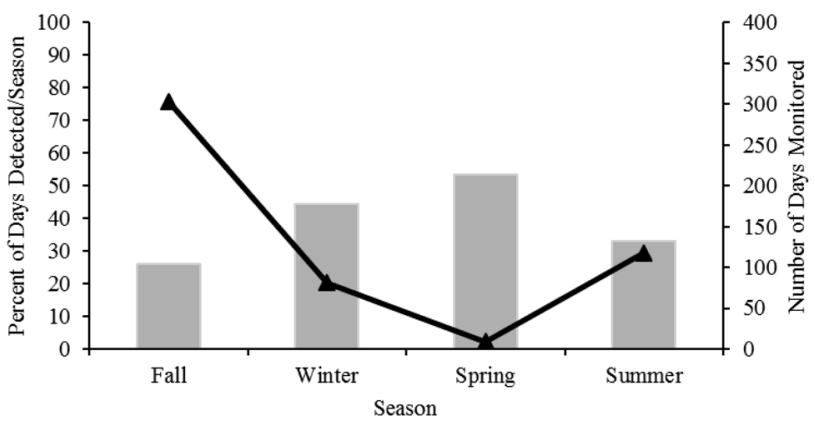

Figure 5.-Bars represent the seasonal recording effort. Diamonds represent the percentage of monitored days with humpback whale detections at each location in a season.

ern resident detections in the late summer/fall. Mammal eating "transient" killer whales were detected throughout the year at all sites.

There was not sufficient sample size to complete statistical analyses for each killer whale ecotype or group separately. A one-way ANOVA showed no significant difference in the seasonal occurrence of killer whales at all sites combined $(F(3,44)=2.17$, $P=0.11)$. There was a significant difference in the year-round occurrence of killer whales among the sites $(F(3,44)=7.46, P=0.00)$, with a significant difference between the Cape Flattery offshore site and the two southern sites (Tukey's test, $P<0.05$ ).

\section{Discussion}

Utilizing a loose network of passive acoustic recorders, we have been able to characterize the spatial and seasonal occurrence of several cetacean species on the Washington coast during times of the year in which aerial and ship surveys are not practical. These results can also be combined with previous visual and acoustic survey results that have been limited temporally and spatially to describe year-round occurrence of these species. Additionally, we provide a baseline to monitor yearly shifts in occurrence due to changing population demographics, oceanographic conditions, or anthropogenic inputs.

Gray whale detections at all sites monitored corresponded with the timing of migration south to the breeding grounds off Baja, Calif., usually starting in November (Swartz et al., 2006) and back north to feeding grounds in the Bering and Chukchi Seas beginning in mid-February (Poole, 1984). The winter peak in detections was also found in previous acoustic monitoring at nearby sites along the southern Washington coast (Sirovic et al., 2011). The migration signal was weakest at the two more offshore sites and strongest at the two inshore sites, which may be due to the tendency of this species to migrate close to shore (Shelden and Laake, 2002). The year round occurrence of gray whale detections at these sites, which were chosen due to their proximity to areas of high primary productivity, may be due to gray whales that do not migrate north and spend the summer feeding off the Oregon and Washington coasts (Calambokidis et al., 2002).

Humpback whale detections also corresponded to known migratory patterns (Calambokidis et al., 2001) with decreased detections in the winter and spring, the period that humpback whales are encountered on their breeding grounds in Hawaii and Mexico. While detections decreased during the winter and spring, the detections during these seasons indicate that humpback whales can be found along the Washington coast throughout the year.

These results are in agreement with 

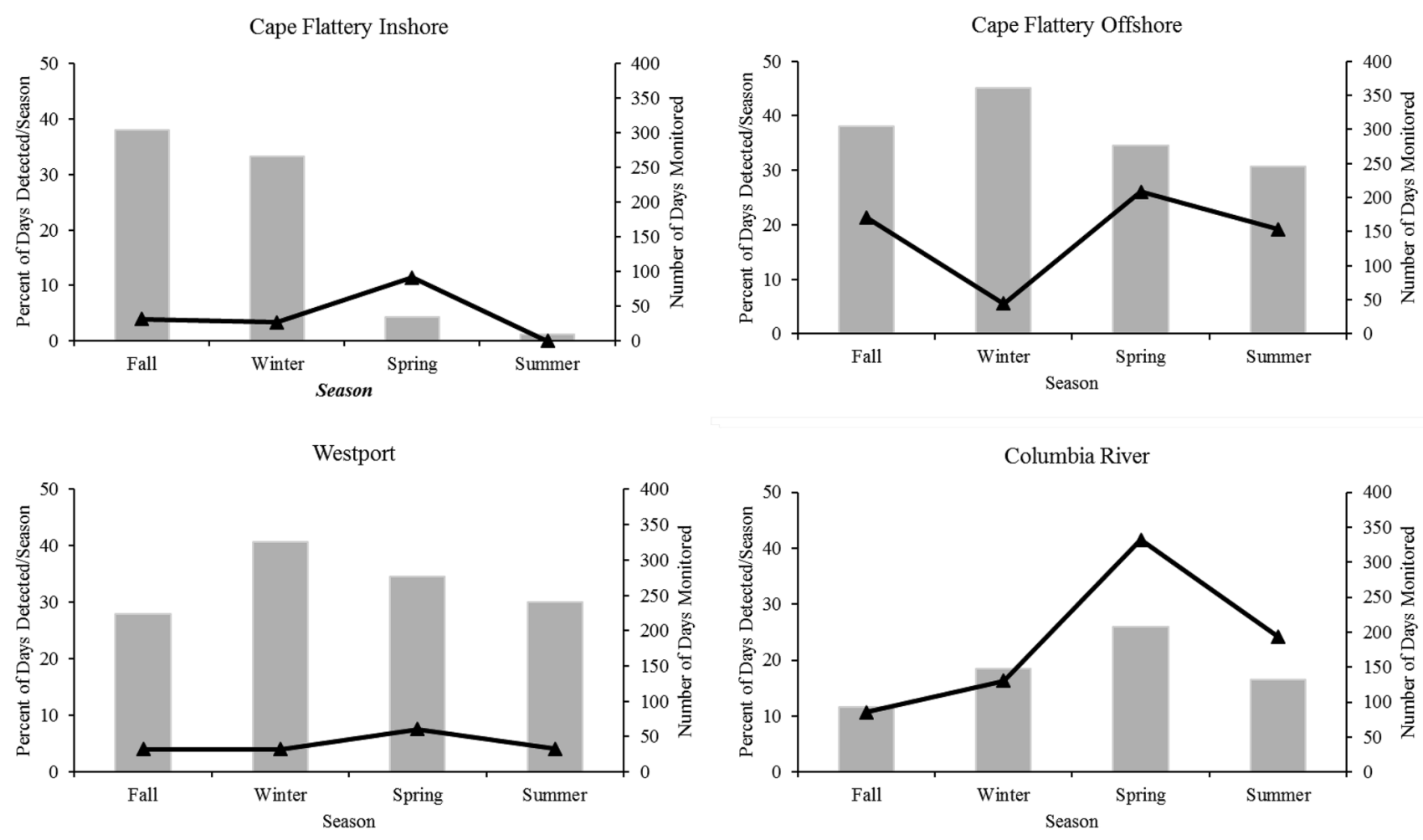

Figure 6.-Bars represent the seasonal recording effort. Diamonds represent the percentage of monitored days with sperm whale detections at each location in a season.

acoustic monitoring at two sites along the southern Washington coast beginning in 2004 (Sirovic et al., 2011; Sirovic et al., 2012; Trickey et al., 2015), but earlier winter systematic visual surveys did not observe humpbacks during winter months (Shelden et al., 2000; Green et al. ${ }^{2}$ ). This may be an emerging pattern of occurrence. The northeast Pacific humpback whale population has grown to pre-whaling estimates of abundance (Barlow et al., 2011) and has seasonally expanded its range to include areas previously not used (Seely et al., 2017). The higher occurrence at the Cape Flattery offshore site is probably due to its proximity to an important feeding area off the northern Washington coast (Calambokidis et al., 2004).

Sperm whales had previously been reported off the Washington Coast in all seasons except winter (Sirovic et al., 2011; Green et al. ${ }^{2}$ ), but in this study they were detected at each site during these months at low levels. During previous systematic surveys, sperm whales were not observed in the shelf waters off the Washington coast (Barlow and Forney, 2007; Green et $\mathrm{al}^{2}{ }^{2}$ ) where all of our recorders were located. The greater number of detections at the Columbia River and Cape Flattery offshore sites may be due to proximity of these moorings to the Astoria and Nitinat canyons, respectively, as sperm whale density has been shown to be correlated with areas of steep underwater topography (Jaquet and Whitehead, 1996). The smaller numbers of detections at the Cape Flattery inshore and Westport sites may be indicative of whales transiting through the near-shore waters of Washington State, which has been observed in previous satellite tagging studies (Straley et al., 2014).

Moore and Barlow (2014) found that the number of sperm whales in the California Current has increased, and estimate a two-fold increase from 1991 to 2008. These are most likely adult males traveling alone or in pairs. Sperm whale distribution is of particular management interest due to their endangered status and interactions with fisheries (Hucke-Gaete et al., 2004; Sigler et al., 2008), and visual surveys for this species can be challenging due to the limited amount of time they spend at the surface. While diving, sperm whales regularly make relatively loud clicks making them amenable to acoustic detection and monitoring to assess seasonal occurrence and distribution (Barlow and Taylor, 2005).

Killer whale occurrence at the two southern sites was highest from January to June. This is primarily due to the increased presence of southern resident killer whales, which is likely driven by the timing of Chinook salmon, Oncorhynchus tshawytscha, returning to the Columbia River (Han- 

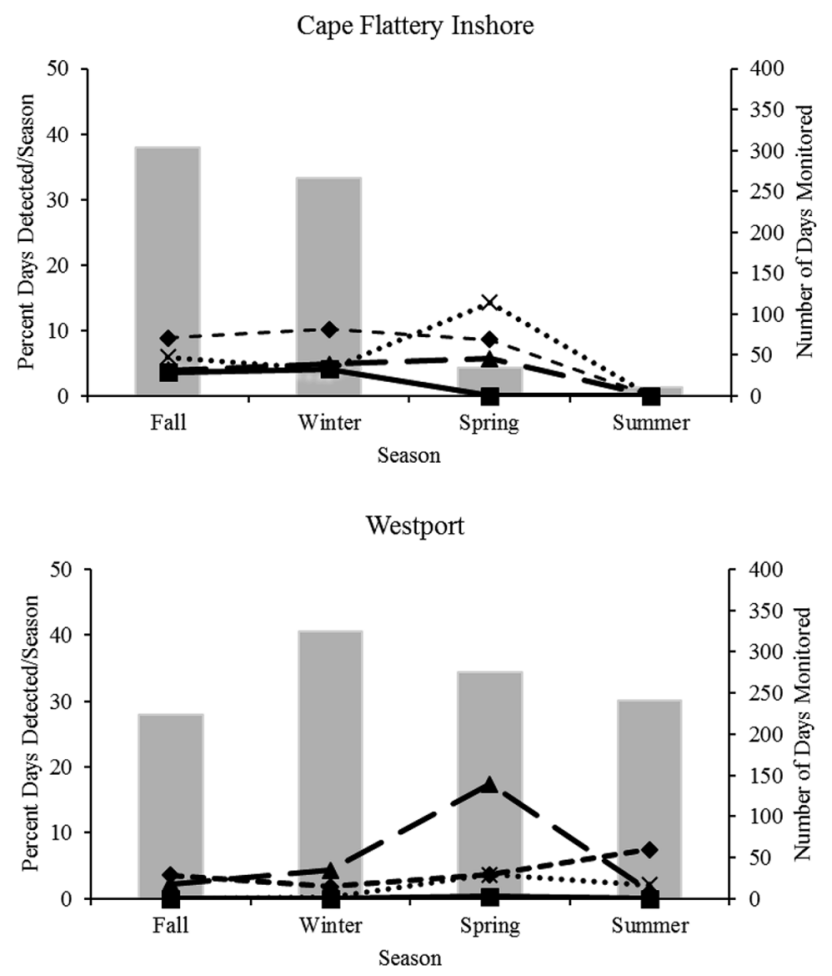
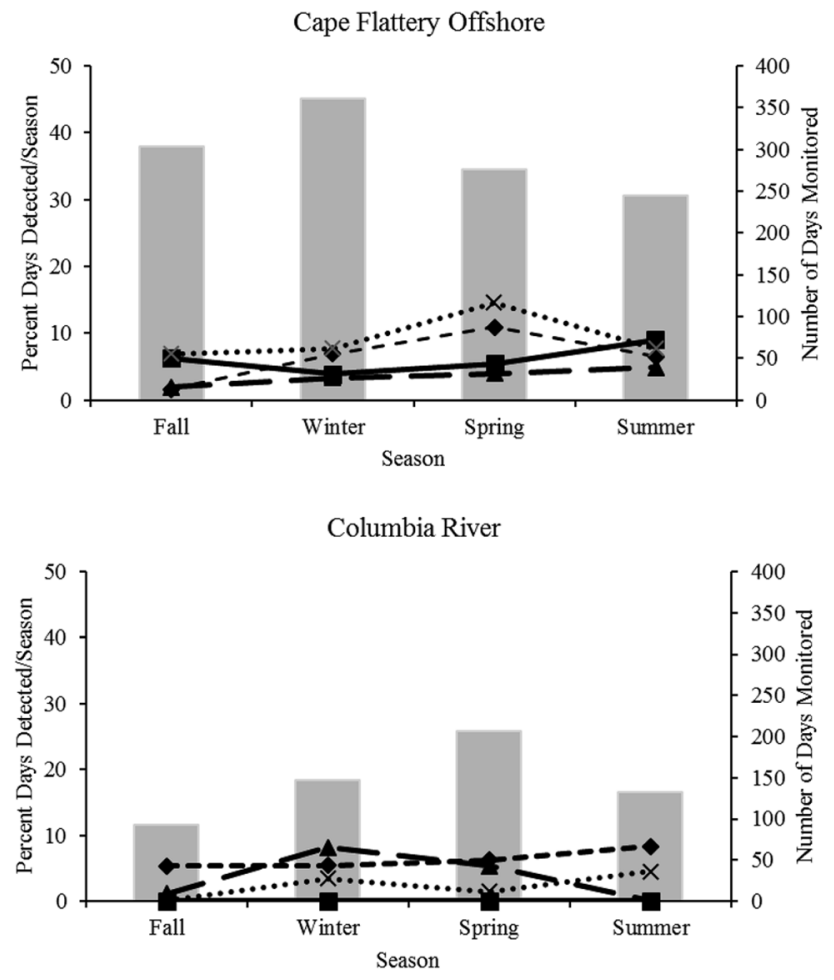

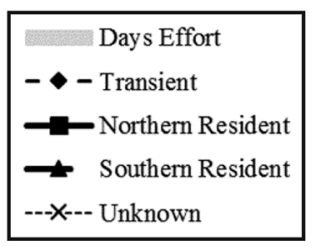

Figure 7.-Bars represent the seasonal recording effort. Lines and symbols represent the percentage of monitored days with killer whale detections at each location in a season: ' $x$ ' represents unknown killer whales, triangle represents southern resident killer whales, squares represent northern resident killer whales, and diamonds represent transient killer whales. son et al., 2013; Rice et al., 2017). By June, transient killer whale detections become more common, even though they are detected at low levels at both sites throughout the year. Rice et al. (2017) also found increased transient killer whale detections in the spring and early summer at two sites along the Washington coast from 2004 to 2013. This timing corresponds to harbor seal, Phoca vitulina, pupping season on the Washington coast (Seekins ${ }^{5}$ ) and the usual return of resident killer whales to inland waters (Hauser et al., 2007). Both resident and transient killer whales were

\footnotetext{
${ }^{5}$ Seekins, B. 2009. Harbor seal pupping timeframes in Washington State (avail. online at http://www.westcoast.fisheries.noaa.gov/publications/gis_maps/maps/marine_mammals/sealpups-timing.pdf (accessed 8 Apr. 2013)).
}

detected more often at the two northern sites which may be a result of the moorings proximity to important foraging areas and the Straits of Juan de Fuca (Baird and Dill, 1995; Ford et al., 2010; Hanson et al., 2010) and corresponds to previous monitoring in the area (Riera et al., 2011; Riera, 2012).

Passive acoustic monitoring has been shown to be an effective tool for examining cetacean occurrence and seasonality in areas of conservation or mitigation interest that are relatively small such as military ranges, renewable energy installations, and marine protected areas (Hazen et al., 2011; Oleson and Hildebrand, 2012; Lammers et al., 2013). It is unclear if it is appropriate to use the results from a single site to infer movements and seasonality on a larger scale, because little is known about variability in distribution of many species across seasons and locations. The results of this study indicate that caution should be used when extrapolating the results of site-specific monitoring to a larger scale. The seasonal occurrence of the four species monitored was variable between the four sites, even amongst those sites that were closest in proximity. For example, gray whales were detected throughout the summer months at the Columbia River site, while they were absent during these months at the other southern site, Westport. And while the acoustic environment may differ among the sites, there were no consistent patterns observed that indicated reduced detection ranges at any given site.

Year-round acoustic monitoring also indicates that species that under- 
take long-distance annual migrations, such as gray, humpback, and sperm whales, use parts of the Washington coast for the entire year. This information is essential for estimating the potential for human interactions, such as entanglement or ship strike, to these species and for monitoring changes in migration timing and seasonal occurrence over time.

\section{Acknowledgments}

The authors thank Michel Richlen, Polly Fisher, and Ken Sexton for assistance with the EAR's. Special thanks are due to Tim Nesseth, NOAA, PMEL, for his concerted efforts to deploy and recover these recorders. Additional mooring support was provided by Steve Smith, Michael Craig, Michael Strick, and Rick Miller, NOAA Pacific Marine Environmental Laboratory, and Eric Boget, Applied Physics Laboratory, University of Washington. We appreciate all the assistance with the mooring deployment/recoveries by the officers and crews of the following vessels: R/V Centennial, R/V Corliss, F/V Cape Windy, R/V McArthur II, R/V Forerunner, R/V Elakha, R/V Pluteus, and R/V Mussel Point. Damon Holzer, NMFS Northwest Fisheries Science Center, provided the acoustic recorder map. Eric Ward provided comments that greatly improved this manuscript. Research was conducted in the Olympic Coast National Marine Sanctuary under permits OCNMS-2005-003, OCNMS-2005-14, OCNMS-2009-005, and in the Gulf of the Farallons National Marine Sanctuary under permit GFNMS-2007-004. Funding for this work was provided by the NMFS Northwest Fisheries Science Center.

\section{Literature Cited}

Allen, S. E., C. Vindeirinho, R. E. Thomson, M. G. Foreman, and D. L. Mackas. 2001. Physical and biological processes over a submarine canyon during an upwelling event. Can. J. Fish. Aquat. Sci. 58:671-684 (doi: https:// doi.org/10.1139/f01-008)

Au, W. W., A. A. Pack, M. O. Lammers, L. M. Herman, M. H. Deakos, and K. Andrews. 2006. Acoustic properties of humpback whale songs. J. Acoustical Soc. Am. 120:1,103-1,110 (doi: https://doi.org/ 10.1121/1.2211547).
Baird, R. W., and L. M. Dill. 1995. Occurrence and behavior of transient killer whales: seasonal and pod-specific variability, foraging behavior, and prey handling. Can. J. Zool. 73:1,300-1,311 (doi: https://doi.org/10.1139/ z95-154).

Barlow, J. 2010. Cetacean abundance in the CA current estimated from a 2008 ship-based line-transect survey. U.S. Dep. Commer., NOAA Tech. Memo. NOAA-TM-NMFSSWFSC-456, $24 \mathrm{p}$. and B. L. Taylor. 2005. Estimates of sperm whale abundance in the northeastern temperate Pacific from a combined acoustic and visual survey. Mar. Mammal Sci. 21:429-445 (doi: https://doi. org/10.1111/j.1748-7692.2005.tb01242.x). and K. A. Forney. 2007. Abun-

dance and population density of cetaceans in the California Current ecosystem. Fish. Bull. 105:509-526.

J. Calambokidis, E. A. Falcone, C. S. Baker, A. M. Burdin, P. J. Clapham, J. K. B. Ford, C. M. Gabriele, R. LeDuc, D. K. Mattila, T. J. Quinn, L. Bracho-Rojas, J. M. Straley, B. L. Taylor, J. R. Urban, P. Wade, D. Weller, B. H. Witteveen, and M. Yamaguchi. 2011. Humpback whale abundance in the North $\mathrm{Pa}$ cific estimated by photographic capture-recapture with bias correction from simulation studies. Mar. Mammal Sci. 27:793-818 (doi: https://doi.org/10.1111/j.1748-7692.2010. 00444.x).

Barrett-Lennard, L., J. K. B. Ford, and K. A. Heise. 1996. The mixed blessing of echolocation; difference in sonar use by fish-eating and mammal eating killer whales. Animal Behavior 51:553-565 (doi: https://doi. org/10.1006/anbe.1996.0059).

Calambokidis, J., G. H. Steiger, J. M. Straley, L. M. Herman, S. Cerchio, D. R. Salden, J. R. Urban, J. K. Jacobsen, O. von Ziegesar, K. C. Balcomb, C. M. Gabriele, M. E. Dahlheim, S. Uchida., G. Ellis, Y. Miyamura, P. P. Ladron de Guevara, M. Yamaguchi, F. Sato, S. A. Mizroch, L. Schlender, K. Rasmussen, J. Barlow, and T. J. Quinn II. 2001. Movements and population structure of humpback whales in the North Pacific. Mar. Mammal Sci. 17(4):769-794 (doi: https://doi. org/10.1111/j.1748-7692.2001.tb01298.x). J. D. Darling, V. Deecke, P. Gearin, M. Gosho, W. Megill, C. M. Tombach, D. Goley, C. Torpova, and B. Gisborne. 2002. Abundance, range and movements of a feeding aggregation of gray whales (Eschrichtius robustus) from California to southeastern Alaska in 1998. J. Cetacean Res. Manage. 4:267-276.

G. H. Steiger, D. K. Ellifrit, B. L. Troutman, and C. E. Bowlby. 2004. Distribution and abundance of humpback whales (Megaptera novaeangliae) and other marine mammals off the northern Washington coast. Fish. Bull. 102:563-580.

Carretta, J. V., S. M. Wilkin, M. M. Muto, K. Wilkinson, and J. Rusin. 2014a. Sources of human-related injury and mortality for U.S. Pacific west coast marine mammal stock assessments: 2008-2012. U. S. Dep. Commer., NOAA Tech. Memo. NOAA-TM-NMFSSWFSC-533, 114 p

E. Oleson, D. W. Weller, A. R. Lang, K. A. Forney, J. Baker, M. B. Hanson, K. K. Martien, M. M. Muto, A. J. Orr, H. Huber, M. S. Lowry, J. Barlow, D. Lynch,
L. Caswell, R. L. Brownell, and D. Mattila. 2014b. U.S. Pacific marine mammal stock assessments, 2013. U.S. Dep. Commer., NOAA Tech. Memo. NOAA-TM-NMFSSWFSC-532, $104 \mathrm{p}$.

Crane, N. L., and K. Lashkari. 1996. Sound production of gray whales, Eschrichtius robustus, along their migration route: a new approach to signal analysis. J. Acoustical Soc. Am. 100:1,878-1,886 (doi: https://doi. org/10.1121/1.416006)

Dahlheim, M. E. 1987. Bio-acoustics of the gray whale, Eschrichtius robustus. Ph.D. thesis, Univ. B.C., Vancouver, 265 p.

Denman, K. L., and T. M. Powell. 1984. Effects of physical process on the planktonic ecocsystems in the coastal ocean. In $\mathrm{H}$. Barnes (Editor), Oceanography and marine biology, an annual review, p. 116-163. Aberdeen Univ. Press, Aberdeen, U.K.

Douglas, A. B., J. Calambokidis, S. Raverty, S. J. Jeffries, D. M. Lambourn, and S. A. Norman. 2008. Incidence of ship strikes of large whales in Washington State. Mar. Biol. Assoc., U.K. 88:1,121-1,132.

Emmons, C., M. Hanson, and M. Lammers. 2019. Monitoring the occurrence of southern resident killer whales, other marine mammals, and anthropogenic sound in the Pacific Northwest. Prep. for U.S. Navy, U.S. Pacific Fleet, Pearl Harbor, HI. Prep. by NOAA, NMFS, NWFSC under MIPR N00070-17MP-4C419, 25 Feb. 2019, 21 p.

Foote, A. D., and J. A. Nystuen. 2008. Variation in call pitch among killer whale ecotypes. J. Acoustical Soc. Am. 123 (3):1747-1752 (doi: https://doi.org/10.1121/1.2836752).

Ford, J. K. 1989. Acoustic behavior of resident killer whales (Orcinus orca) off Vancouver Island, British Columbia. Can. J. Zool. 67:727-745 (doi: https://doi.org/10.1139/z89105).

G. M. Ellis, P. F. Olesiuk, and K. C. Balcomb. 2010. Linking killer whale survival and prey abundance: food limitation in the oceans' apex predator? Biol. Letters 6:139-142 (doi: https://doi.org/10.1098/ rsbl.2009.0468)

Ford, J. K. B. 1987. A catalogue of underwater calls produced by killer whales (Orcinus orca) in British Columbia. Can. Data Rep. Fish. Aquat. Sci. 633:1-165.

Forney, K. A., and J. Barlow. 1998. Seasonal patterns in the abundance and distribution of California cetaceans, 1991-1992. Mar. Mammal Sci. 14:460-489.

Hanson, M. B., R. W. Baird, J. K. B. Ford, J. Hempelmann-Halos, D. M. Van Doornik, J. R. Candy, C. K. Emmons, G. S. Schorr, B. Gisborne, K. L. Ayers, S. K. Wasser, K. C. Balcomb, K. Balcomb-Bartok, J. G. Sneva, and M. J. Ford. 2010. Species and stock identification of prey consumed by endangered southern resident killer whales in their summer range. Endang. Spec. Res. 11:69-82 (doi: https://doi.org/10.3354/esr00263).

C. K. Emmons, E. J. Ward, J. A. Nystuen, and M. O. Lammers. 2013. Assessing the coastal occurrence of endangered killer whales using autonomous passive acoustic recorders. J. Acoustic Soc. Am. 134:3,486-3,495 (doi: https://doi.org/ $10.1121 / 1.4821206)$.

Hauser, D. W., M. G. Logsdon, E. E. Holmes, G. R. VanBlaricom, and R. W. Osborne. 2007. Summer distribution patterns of southern res- 
ident killer whales Orcinus orca: core areas and spatial segregation of social groups. Mar. Ecol. Prog. Ser. 351:301-310 (doi: https:// doi.org/10.3354/meps07117)

Hazen, E. L., D. P. Nowacek, L. St. Laurent, P. N. Halpin, and D. J. Moretti. 2011. The relationship among oceanography, prey fields, and beaked whale foraging habitat in the Tongue of the Ocean. PLoS One 6:e19269 (doi: https://doi.org/10.1371/journal.pone.0019269).

Hucke-Gaete, R., C. A. Moreno, and J. Arata. 2004. Operational interactions of sperm whales and killer whales with the Patagonian toothfish industrial fishery off Southern Chile. Comm. Conserv. Antarctic Mar. Living Resour. Sci. 11:127-140.

Jaquet, N., and H. Whitehead. 1996. Scale-dependent correlation of sperm whale distribution with environmental features and productivity in the South Pacific. Mar. Ecol. Prog. Ser. 135:1-9 (doi: https://doi.org/10.3354/ meps135001)

S. Dawson, and L. Douglas. 2001. Vocal behavior of male sperm whales: why do they click? J. Acoustical Soc. Am. 109:2254-2259 (doi: https://doi. org/10.1121/1.1360718)

Lammers, M. O., R. E. Brainard, W. W. Au, T. A. Mooney, and K. B. Wong. 2008. An ecological acoustic recorder (EAR) for long-term monitoring of biological and anthropogenic sounds on coral reefs and other marine habitats. J. Acoustical Soc. Am. 123:1,720-1,728 (doi: https://doi.org/10.1121/1.2836780). M. Castellote, R. J. Small, S. Atkinson, J. Jenniges, A. Rosinski, J. N. Oswald, and C. Garner. 2013. Passive acoustic monitoring of Cook Inlet beluga whales (Delphinapterus leucas). J. Acoustical Soc. Am. 134:2,497-2,504 (doi: https://doi.org/ $10.1121 / 1.4816575)$

Mackas, D. L., R. Kieser, M. Saunders, D. R. Yelland, R. M. Brown, and D. F. Moore. 1997. Aggregation of euphausiids and Pacific hake (Merluccius productus) along the outer continental shelf off Vancouver Island. Can. J. Fish. Aquat. Sci. 54:2,080-2,096 (doi: https://doi.org/10.1139/f97-113).

Moore, J. E., and J. P. Barlow. 2014. Improved abundance and trend estimates for sperm whales in the eastern North Pacific from Bayesian hierarchical modeling. Endang. Spec. Res. 25(2):141-150 (doi: https://doi.org/ 10.3354/esr00633)

Oleson, E., and J. Hildebrand. 2012. Marine mammal demographics off the outer Wash- ington coast and near Hawaii. Naval Postgraduate School Rep. NPS-OC-12-001CR, $69 \mathrm{p}$

Poole, M. 1984. Migration corridors of gray whales along the Central California coast, 1980-1982. In M. L. Jones, S. L. Swartz, and $\mathrm{S}$. Leatherwood (Editors), The gray whale, p. 389-407. Acad. Press, N.Y.

Rice, A., V. Deecke, J. Ford, J. Pilkington, E. Oleson, J. Hildebrand, and A. Sirovic. 2017. Spatial and temporal occurrence of killer whale ecotypes off the outer coast of Washington State, USA. Mar. Ecol. Prog. Ser. 572:255-268 (doi: https://doi.org/10.3354/ meps12158).

Riera, A. 2012. Patterns of seasonal occurrence of sympatic killer whale lineages in waters off southern Vancouver Island and Washington state, as determined by passive acoustic monitoring. Univ. Victoria, B.C., M.S. Thesis, $129 \mathrm{p}$.

J. K. B. Ford, J. A. Hildebrand, and N. R. Chapman. 2011. Acoustic monitoring of killer whale populations off the west coast of Vancouver Island. J. Acoustical Soc. Am. 129:2,607-2,607 (doi: https://doi. org/10.1121/1.3588652).

and N. R. Chapman. 2013. Effects of different analysis techniques and recording duty cycles on passive acoustic monitoring of killer whales. J. Acoustical Soc. Am. 134:2,393-2,404 (doi: https://doi. org/10.1121/1.4816552).

Seely, E., R. W. Osborne, K. Koski, and S. Larson. 2017. Soundwatch: eighteen years of monitoring whale watch vessel activities in the Salish Sea. PLOS One. 12(12) e0189764 (doi: https://doi.org/10.1371/journal.pone.0189764)

Shelden, K. E., and J. L. Laake. 2002. Comparison of the offshore distribution of southbound migrating gray whales from aerial survey data collected off Granite Canyon, California, 1979-96. J. Cetacean Res. Manage. 4(1):53-56

D. J. Rugh, J. L. Laake, J. M. Waite, P. J. Gearin, and T. R. Wahl. 2000. Winter observations of cetaceans off the northern Washington Coast. Northwestern Nat. 81(2):54-59 (doi: https://doi.org/10.2307/ 3536664).

Sigler, M. F. C. R. Lunsford, J. M. Straley, and J. B. Liddle. 2008. Sperm whale depredation of sablefish longline gear in the northeast Pacific Ocean. Mar. Mammal Sci. 24:1627 (doi: https://doi.org/10.1111/j.1748-7692. 2007.00149.x).
Sirovic, A., E. M. Oleson, J. Calambokidis, S Baumann-Pickering, A. Cummings, S. Kerosky, L. Roche, A. Simonis, S. M. Wiggins, and J. A. Hilderbrand. 2011. Marine mamma demographics of the outer Washington Coast during 2008-2009. MPL Tech. Memo. 534, 23 p., La Jolla, Calif.

J. A. Hilderbrand, S. Baumann-

Pickering, J. Buccowich, A. Cummins, S Kerosky, L. Roche, A. S. Berga, and S. M Wiggins. 2012. Passive acoustic monitorning of marine mammals in the Northwest Training Range Complex 2011. MPL Tech. Memo. 535,57 p. La Jolla, Calif.

Stimpert, A. K., W. W. Au, S. E. Parks, T. Hurst, and D. N. Wiley. 2011. Common humpback whale (Megaptera novaeangliae) sound types for passive acoustic monitoring. J. Acoustic Soc. Am. 129:476-482 (doi: https://doi org/10.1121/1.3504708).

Straley, J. M., G. S. Schorr, A. M. Thode, J. Calambokidis, C. R. Lunsford, E. M. Chenoweth, V. M. O'Connell, and R. D. Andrews. 2014. Depredating sperm whales in the Gulf of Alaska: local habitat use and long distance movements across putative population boundaries. Endang. Spec. Res. 24:125-135 (doi: https://doi.org/10.3354/esr00595)

Swartz, S., B. L. Taylor, and D. Rugh. 2006 Gray whale Eschrichtius robustus population and stock identity. Mammal Rev. 36:6684 (doi: https://doi.org/10.1111/j.1365-2907. 2006.00082.x).

Thomisch, K., O. Boebel, D. P. Zitterbart, F. Samaran, S. Van Parjs, and I Van Opzeeland. 2015. Effects of subsampling of passive acoustic recordings on acoustic metrics. J. Acoustic Soc. Am. 138:267-278 (https://doi. org/10.1121/1.4922703).

Thomsen, F., D. Franck, and J. K. B. Ford. 2001. Characteristics of whistles from the acoustic repertoire of resident killer whales (Orcinus orca) off Vancouver Island, British Columbia J. Acoustical Soc. Am. 109 (3):1,240-1,246 (doi: https://doi.org/10.1121/1.1349537).

Trickey, J., S. Baumann-Pickering, A. Sirovic, J. A. Hilderbrand, A. M. Brewer, A. J. Debich, S. Herbert, A. C. Rice, B. Thayre, and S. M. Wiggins. 2015. Passive acoustic monitoring for marine mammals in the Northwest Training Range Complex July 2013-April 2014. MPL Tech. Memo. 557, 47 p., La Jolla, Calif.

Weilgart, L. S., and H. Whitehead. 1988. Distinctive vocalizations from mature male sperm whales (Physeter macrocephalus). Can. J. Zool. 66:1,931-1,937 (doi: https://doi. org/10.1139/z88-282). 